\title{
Association between Early Marriage and Other Sociomedical Characteristics with the Cervical Pap Smear Results in Iraqi Women
}

\author{
May Kasim Khalaf', Faris Anwer Rasheed ${ }^{2}$, Saad Abdulrahman Hussain ${ }^{3 *}$ \\ ${ }^{1}$ Al-Elweyia Maternity Teaching Hospital, Baghdad, Iraq \\ ${ }^{2}$ Department of Obstetrics and Gynecology, Al-Kindy Medical College, University of Baghdad, Baghdad, Iraq \\ ${ }^{3}$ Department of Pharmacology and Toxicology, College of Pharmacy, University of Baghdad, Baghdad, Iraq \\ Email: may.qasim@yahoo.com, faris_45@yahoo.com,
}

Received 7 July 2015; accepted 20 September 2015; published 23 September 2015

Copyright (C) 2015 by authors and Scientific Research Publishing Inc.

This work is licensed under the Creative Commons Attribution-NonCommercial International License (CC

BY-NC).

http://creativecommons.org/licenses/by-nc/4.0/

(c) (1) (9) 0 pen Access

\section{Abstract}

Background: The standard screening test for cervical cancer is the Pap smear and cervical cancer is a significant health issue worldwide. Early sexual activity, multiple sexual partnerships, parity, young age at first pregnancy and early marriage are traditional risk factors for developing cervical cancer. The aim of the present study was to assess the effect of early marriage in on the results of Pap smear in Iraqi women. Methods: A cross-sectional study was carried out on 200 women who attended the Women Health Clinic of Al-Elwiya Maternity Teaching Hospital, Baghdad for the period from November 2013 to April 2014. Data were collected through direct interview and a prepared questionnaire including patients' characteristics and Pap smear results. Results: Mean age of studied women was $39.9 \pm 11.4$ years and mean age of marriage was $19 \pm 5$ years. Abnormal Pap results were reported in $63.5 \%$ of them. A significant association was observed between abnormal Pap smear and each of age 20 - 30 years, $\leq 18$ years age at marriage, marriage duration $>10$ years, irregular menstrual cycle, tubal ligation and abnormal medical history $(P<0.05)$. Conclusions: Early marriage was strongly associated with abnormal Pap smear results in Iraqi women.

\section{Keywords}

Pap Smear, Early Marriage, Medical History, Gynecologic Complications

\footnotetext{
${ }^{*}$ Corresponding author.
}

How to cite this paper: Khalaf, M.K., Rasheed, F.A. and Hussain, S.A. (2015) Association between Early Marriage and Other Sociomedical Characteristics with the Cervical Pap Smear Results in Iraqi Women. Advances in Sexual Medicine, 5, 73-82. http://dx.doi.org/10.4236/asm.2015.54009 


\section{Introduction}

World-wide, cervical cancer is considered the fourth most common malignancy and also the fourth most common cause of cancer death in women [1]. However, prevention and decrease mortality rate due to cervical cancer can be achieved by early diagnosis during early stages. In Iraq, there are 10.12 million women (15 years and older) at risk of developing cervical cancer [2]. Current reports indicated that 291 women are diagnosed with cervical cancer every year, and about 142 die from the disease [3]. Moreover, cervical cancer ranks as the 12th most frequent cancer among women in Iraq, and the 10th most frequent cancer among women between 15 and 44 years of age [4]. Early marriage and polygamy play an important role in developing cervical cancer [5]. Common risks for cervical cancer and child marriage are low socioeconomic status, poor access to health care, and husbands who had multiple sex partners [6]. In Iraq, 28\% of girls with age of 15 - 18 years are married [7]. Although the cervical cancer has a multifactorial risk, infection with human papilloma virus (HPV) and lack of effective screening have been identified as major components in the development of pre-invasive and invasive types of this disease [8]. First infection with HPV often occurs soon after first sexual intercourse [9], making early age at first intercourse a reasonable proxy for early age at first exposure to HPV [10]. Despite the high prevalence of cervical cancer, women's knowledge about HPV, cervical cancer and cervical screening is limited [11]. Moreover, women's knowledge and awareness of cervical cancer are considered determinant regarding the uptake and success of cervical cancer screening [12]. The benefits of screening for cervical cancer based on Papanicolaou smear test (Pap test) are well established; routine Pap testing has led to the decline in the incidence and mortality rate of cervical cancer [13]. In early marriage, the increased risk of HPV was attributed to biological predisposition of the immature cervix during adolescence, which may be more susceptible to persistent HPV infections and therefore have a greater risk of cancer development [14]. The present study was designed to evaluate the effect of early marriage on the results of Pap smear performed for Iraqi women aged $30-40$ years.

\section{Methods}

\subsection{Study Design}

The present cross sectional study was carried out in the women health clinic of Al-Elwiya Maternity Teaching hospital form $1^{\text {st }}$ of November, 2013 to $1^{\text {st }}$ of April, 2014. It includes 200 post pubertal married women who attended the Women Health Clinic of Al-Elwiya Maternity Teaching hospital. Each woman who fulfils the inclusion criteria of being Post pubertal and married or previously married was included, and those with known cases of malignancy, duration of marriage less than one year, cauterization and cone biopsy, cervical scaring due to previous damage in labor, human papilloma virus infection and received any vaginal treatment or douches 72 hours before inclusion were excluded. The study protocol was approved by the local committee of research ethics and the committee of the Arabic Board of Medical Specialties; signed informed consents were obtained from all participants.

\subsection{Data Collection and Evaluation}

After full clinical investigation, data were collected from each women according to a questionnaire specially prepared for this purpose. It includes demographic data, lifestyle and social information, obstetrical, gynecological and medical history, and sexual history. All anthropometric measurements were performed according to standard methods [15]. Pap smear test was performed between $10^{\text {th }}-20^{\text {th }}$ days of the menstrual cycle by rotating Ayer's spatula 360 degrees around transformation zone of cervix, while cervical smears were taken by a special endocervical brush. The results were evaluated and interpreted according to the Bethesda system 2001 (ASC-US) [16]. Any case with HPV were was excluded for the aim of focusing on other predisposing factors of cervical carcinoma especially early marriage.

\subsection{Statistical Analyses}

All results were analyzed using Statistical Package for Social Sciences (SPSS) version 17. Descriptive values were presented as mean $\pm \mathrm{SD}$, frequencies and percentages. Multiple contingency tables and appropriate statistical tests were performed utilizing Chi-square for categorical variables and $t$-test for continuous variables. The level of significance ( $P$ value) was set at $<0.05$. Partial correlation was used to evaluate the effects of other factors and measure the power of studied variables. Binary logistic regression analysis was used for prediction of 
group membership and also provides knowledge of the relationships and strengths among the variables.

\section{Results}

Table 1 showed the sociodemographic characteristics of the participants. Mean age of marriage was $19 \pm 5$ years, half of them $\leq 18$ years and the other half $>18$ years. The mean duration of marriage was $20 \pm 12$ years, $29.5 \%$ women were with marriage duration $\leq 10$ years and $70.5 \%$ with marriage duration $>10$ years. Mean age at first delivery was $21 \pm 6$ years, $39.8 \%$ were $\leq 18$ years old at first delivery and $60.2 \%$ were $>18$ years old at first delivery. $75.5 \%$ of the women were living in urban areas and $24.5 \%$ of them in rural areas. $72 \%$ of the women had a good socioeconomic history, while $28 \%$ of them had a bad socioeconomic history. $82.5 \%$ of women were non-smokers and $17.5 \%$ were current smokers. Meanwhile, 9.5\% of women had normal BMI, $52.5 \%$ overweight and $38 \%$ were obese (Table 2). Table 2 also showed that the mean gravidity of participants was $6 \pm 2$, mean parity was $5 \pm 2$ and mean abortion was $2 \pm 1$. Additionally, $85.2 \%$ of women had normal vaginal delivery and $14.8 \%$ had cesarean section. Moreover, the mean age of menarche of women was $13 \pm 1$ years, on the other hand, $62 \%$ of the women had regular menstrual cycle and $38 \%$ of them had irregular menstrual cycles. In Table 3 , half of studied women used no contraceptive methods, $19 \%$ used COCP, $4 \%$ used IUCD, $6.5 \%$ used progesterone, $8.5 \%$ used barrier, $6.5 \%$ used coitus interrupts and 3.5\% used tubal ligation. About two thirds of the studied women had active sexual history and $31.5 \%$ of them had inactive sexual history. Table 3 also showed that only $17.5 \%$ of the studied women had history of medical disease, $79.5 \%$ had no previous gynecological operations and $20.5 \%$ had previous gynecological operations. $66.5 \%$ of the women had no previous surgical operations and $33.5 \%$ of them had previous surgical operations. Mean interval between marriage and first Pap test was $17 \pm 10$ years. In Table 4, normal Pap results were represented by $36.5 \%$ of women, while those of abnormal results represent $63.5 \%$. Abnormal smears were reported in $36.5 \%$ of women, while $33.5 \%$ showed atypical squamous cells, $14.5 \%$ with low grade squamous intraepithelial lesion, $8 \%$ had high grade squamous intraepithelial lesion, and $5 \%$ had atypical glandular cells; meanwhile, no women had adenocarcinoma according to Bethesda classification. Table 5 showed that $85.3 \%$ of the women with age 20 - 30 years had abnormal Pap results and there was significant association between women with age group 20 - 30 years and abnormal Pap results $(P=0.001)$. Additionally, a statistically significant association was reported between early age at marriage and abnormal Pap results $(P=0.001)$, and $87 \%$ of women with early age at marriage ( $\leq 18$ years) had abnormal Pap results. Significant association was reported between long duration of marriage duration ( $>10$ years) and abnormal Pap results, where $68.8 \%$ of women with long marriage duration had abnormal Pap results. Moreover, Table 5 shows no significant association was observed between residences, occupation and socioeconomic history of women and their Pap results $(P>0.05)$. The present study shows no significant association between smoking, BMI and mode of delivery of studied women with their Pap results $(P>0.05)$, and significant association was reported only between irregular menstrual cycle and abnormal Pap results $(P=0.04)$ (Table 6). Table 7 shows significant association between women used COCP contraceptive method and abnormal Pap results $(89.5 \% ; P=0.001)$, and women with abnormal medical history were significantly associated with abnormal Pap results $(88.6 \% ; P=0.001)$. A significant association was also observed between women with no history of surgical operations and abnormal Pap results $(P=0.001)$; meanwhile, no significant association was observed between each of sexual and gynecological history with Pap results $(P>0.05)$ (Table 7). Analysis of variables indicates significant association between early age at marriage and abnormal Pap results $(P=0.001)$, where the mean age of women at marriage with abnormal results was $16.9 \pm 4.6$ years. Moreover, women with lower incidence of abortions significantly showed abnormal Pap results $(P=0.001)$, and those with early age at first delivery were also significantly associated with abnormal Pap results $(P=0.001)$, where the mean age at first delivery was $18.5 \pm 5.2$ years. Similarly, a significant association was reported between early age at menstruation (menarche) and abnormal Pap results $(P=0.001)$, while no significant association was observed between gravidity, parity, frequency of coitus and interval between marriage and Pap test with Pap results (Table 8). After controlling all significant variables with abnormal Pap results by partial correlation test, a significant association was observed between early age at marriage and abnormal Pap results $(P=0.004)$.

\section{Discussion}

Many reports have revealed that early age marriage of girls who are not mature physically may predispose to physical problems, mood disorders, depression, and anxiety [17]. Moreover, the first year of marriage increases 
Table 1. Sociodemographic characteristics of studied women.

\begin{tabular}{|c|c|c|}
\hline Variable & No. & $\%$ \\
\hline \multicolumn{3}{|c|}{ Age $(39.9 \pm 11.4$ years $)$} \\
\hline $20-30$ years & 34 & 17 \\
\hline $31-40$ years & 78 & 39 \\
\hline $41-50$ years & 60 & 30 \\
\hline$>50$ years & 28 & 14 \\
\hline Total & 200 & 100 \\
\hline \multicolumn{3}{|c|}{ Age of marriage $(19 \pm 5$ years $)$} \\
\hline$\leq 18$ years & 100 & 50 \\
\hline$>18$ years & 100 & 50 \\
\hline Total & 200 & 100 \\
\hline \multicolumn{3}{|c|}{ Marriage duration ( $20 \pm 12$ years) } \\
\hline$\leq 10$ years & 59 & 29.5 \\
\hline$>10$ years & 141 & 70.5 \\
\hline Total & 200 & 100 \\
\hline \multicolumn{3}{|c|}{ Age at first delivery ( $21 \pm 6$ years) } \\
\hline$\leq 18$ years & 78 & 39.8 \\
\hline$>18$ years & 118 & 60.2 \\
\hline Total & 196 & 100 \\
\hline \multicolumn{3}{|c|}{ Residence } \\
\hline Urban & 151 & 75.5 \\
\hline Rural & 49 & 24.5 \\
\hline Total & 200 & 100 \\
\hline \multicolumn{3}{|c|}{ Occupation } \\
\hline Housewife & 175 & 87.5 \\
\hline Employed & 25 & 12.5 \\
\hline Total & 200 & 100 \\
\hline \multicolumn{3}{|c|}{ Socioeconomic history } \\
\hline Good & 144 & 72 \\
\hline $\mathrm{Bad}$ & 56 & 28 \\
\hline Total & 200 & 100 \\
\hline
\end{tabular}

Table 2. Lifestyle and health characteristics of studied women.

\begin{tabular}{cccc}
\hline Variable & No. & $\%$ \\
\hline & Smoking & & \\
\hline Non & 165 & 82.5 \\
Current smoker & 35 & 17.5 & 100 \\
\hline
\end{tabular}




\section{Continued}

\begin{tabular}{|c|c|c|}
\hline \multicolumn{3}{|c|}{$B M I\left(27.5 \pm 3.3 \mathrm{Kg} / \mathrm{m}^{2}\right)$} \\
\hline Normal & 19 & 9.5 \\
\hline Overweight & 105 & 52.5 \\
\hline Obese & 76 & 38 \\
\hline Total & 200 & 100 \\
\hline \multicolumn{3}{|c|}{ Gravidity $(6 \pm 2)$} \\
\hline \multicolumn{3}{|c|}{ Parity $(5 \pm 2)$} \\
\hline \multicolumn{3}{|c|}{ Abortion $(2 \pm 1)$} \\
\hline \multicolumn{3}{|c|}{ Mode of delivery } \\
\hline Normal vaginal & 167 & 85.2 \\
\hline Cesarean section & 29 & 14.8 \\
\hline Total & 196 & 100 \\
\hline \multicolumn{3}{|c|}{ Menarche (13 \pm 1 years) } \\
\hline \multicolumn{3}{|c|}{ Regularity of menstrual cycle } \\
\hline Regular & 124 & 62 \\
\hline Irregular & 76 & 38 \\
\hline Total & 200 & 100 \\
\hline
\end{tabular}

Table 3. Health and clinical characteristics of studied women.

\begin{tabular}{|c|c|c|}
\hline Variable & No. & $\%$ \\
\hline \multicolumn{3}{|c|}{ Contraceptive methods } \\
\hline No & 104 & 52 \\
\hline $\mathrm{COCP}$ & 38 & 19 \\
\hline IUCD & 8 & 4 \\
\hline Progesterone & 13 & 6.5 \\
\hline Barrier & 17 & 8.5 \\
\hline Coitus interrupts & 13 & 6.5 \\
\hline Tubal ligation & 7 & 3.5 \\
\hline Total & 200 & 100 \\
\hline \multicolumn{3}{|c|}{ Sexual history } \\
\hline Active & 137 & 68.5 \\
\hline Inactive & 63 & 31.5 \\
\hline Total & 200 & 100 \\
\hline \multicolumn{3}{|c|}{ Medical history } \\
\hline Normal & 165 & 82.5 \\
\hline Abnormal & 35 & 17.5 \\
\hline Total & 200 & 100 \\
\hline \multicolumn{3}{|c|}{ Gynecological operations } \\
\hline No & 159 & 79.5 \\
\hline Yes & 41 & 20.5 \\
\hline Total & 200 & 100 \\
\hline \multicolumn{3}{|c|}{ Surgical operations } \\
\hline No & 133 & 66.5 \\
\hline Yes & 67 & 33.5 \\
\hline Total & 200 & 100 \\
\hline
\end{tabular}

Interval between marriage and Pap test ( $17 \pm 10$ years). 
Table 4. Pap results of studied women according to Bethesda classification $(\mathrm{n}=200)$.

\begin{tabular}{ccc}
\hline Variable & No. & $\%$ \\
\hline & Pap results & \\
Normal & 73 & 36.5 \\
Abnormal & 127 & 63.5 \\
Total & 200 & 100 \\
Cytological classifications of Pap results & 36.5 \\
Normal & 73 & 33.5 \\
Atypical squamous cells & 67 & 14.5 \\
Low grade squamous intraepithelial lesion & 29 & 8 \\
High grade squamous intraepithelial lesion & 16 & 5 \\
Atypical glandular cells & 10 & 0 \\
Adenocarcinoma & 0 & 100 \\
\hline
\end{tabular}

Table 5. Distribution of sociodemographic characteristics according to Pap results.

\begin{tabular}{|c|c|c|c|c|c|c|c|c|}
\hline \multirow{2}{*}{ Variable } & \multicolumn{2}{|c|}{ Normal Pap } & \multicolumn{2}{|c|}{ Abnormal Pap } & \multicolumn{2}{|c|}{ Total } & \multirow{2}{*}{$\chi^{2}$} & \multirow{2}{*}{$P$} \\
\hline & No. & $\%$ & No. & $\%$ & No. & $\%$ & & \\
\hline \multicolumn{7}{|c|}{ Age (years) } & \multirow{5}{*}{18.9} & \multirow{5}{*}{0.001} \\
\hline $20-30$ & 5 & 14.7 & 29 & 85.3 & 34 & 100 & & \\
\hline $31-40$ & 40 & 51.3 & 38 & 48.7 & 78 & 100 & & \\
\hline $41-50$ & 15 & 25 & 45 & 75 & 60 & 100 & & \\
\hline$>50$ & 13 & 46.4 & 15 & 53.6 & 28 & 100 & & \\
\hline \multicolumn{8}{|c|}{ Age at marriage (years) } & \multirow{3}{*}{0.001} \\
\hline$\leq 18$ & 13 & 13 & 87 & 87 & 100 & 100 & 47.6 & \\
\hline$>18$ & 60 & 60 & 40 & 40 & 100 & 100 & & \\
\hline \multicolumn{7}{|c|}{ Marriage duration (years) } & \multirow{3}{*}{5.7} & \multirow{3}{*}{0.01} \\
\hline$\leq 10$ & 29 & 49.2 & 30 & 50.8 & 59 & 100 & & \\
\hline$>10$ & 44 & 31.2 & 97 & 68.8 & 141 & 100 & & \\
\hline \multicolumn{7}{|c|}{ Residence } & \multirow{3}{*}{0.9} & \multirow{3}{*}{0.7} \\
\hline Urban & 56 & 37.1 & 95 & 62.9 & 151 & 100 & & \\
\hline Rural & 17 & 34.7 & 32 & 65.3 & 49 & 100 & & \\
\hline \multicolumn{7}{|c|}{ Occupation } & \multirow{3}{*}{0.5} & \multirow{3}{*}{0.4} \\
\hline Housewife & 64 & 36 & 111 & 64.0 & 175 & 100 & & \\
\hline \multirow[t]{2}{*}{ Employed } & 11 & 44 & 14 & 56.0 & 25 & 100 & & \\
\hline & \multicolumn{4}{|c|}{ Socioeconomic history } & & & \multirow{3}{*}{3.1} & \multirow{3}{*}{0.07} \\
\hline Good & 58 & 40.3 & 86 & 59.7 & 144 & 100 & & \\
\hline $\mathrm{Bad}$ & 15 & 26.8 & 41 & 73.2 & 56 & 100 & & \\
\hline
\end{tabular}


Table 6. Distribution of lifestyle and health characteristics of the women according to Pap results.

\begin{tabular}{|c|c|c|c|c|c|c|c|c|}
\hline \multirow{2}{*}{ Variable } & \multicolumn{2}{|c|}{ Normal Pap } & \multicolumn{2}{|c|}{ Abnormal Pap } & \multicolumn{2}{|c|}{ Total } & \multirow{2}{*}{$\chi^{2}$} & \multirow{2}{*}{$P$} \\
\hline & No. & $\%$ & No. & $\%$ & No. & $\%$ & & \\
\hline \multicolumn{9}{|c|}{ Smoking } \\
\hline Non & 58 & 35.2 & 107 & 64.8 & 165 & 100 & 0.7 & 0.3 \\
\hline Current & 15 & 42.9 & 20 & 57.1 & 35 & 100 & & \\
\hline \multicolumn{8}{|c|}{$B M I$} & \multirow{4}{*}{0.4} \\
\hline Normal & 6 & 31.6 & 13 & 68.4 & 19 & 100 & \multirow{3}{*}{1.6} & \\
\hline Overweight & 35 & 33.3 & 70 & 66.7 & 105 & 100 & & \\
\hline Obese & 32 & 42.1 & 44 & 57.9 & 76 & 100 & & \\
\hline \multicolumn{8}{|c|}{ Mode of delivery } & \multirow{3}{*}{0.1} \\
\hline Normal & 55 & 32.9 & 112 & 67.1 & 167 & 100 & 2.5 & \\
\hline \multirow[t]{2}{*}{ Cesarean } & 14 & 48.3 & 15 & 51.7 & 29 & 100 & & \\
\hline & \multicolumn{4}{|c|}{ Regularity of menstrual cycle } & & & \multirow{3}{*}{4.1} & \multirow{3}{*}{0.04} \\
\hline Regular & 52 & 41.9 & 72 & 58.1 & 124 & 100 & & \\
\hline Irregular & 21 & 27.6 & 55 & 72.4 & 76 & 100 & & \\
\hline
\end{tabular}

Table 7. Distribution of clinical characteristics of the women according to Pap results.

\begin{tabular}{|c|c|c|c|c|c|c|c|c|}
\hline \multirow{2}{*}{ Variable } & \multicolumn{2}{|c|}{ Normal Pap } & \multicolumn{2}{|c|}{ Abnormal Pap } & \multicolumn{2}{|c|}{ Total } & \multirow{2}{*}{$\chi^{2}$} & \multirow{2}{*}{$P$} \\
\hline & No. & $\%$ & No. & $\%$ & No. & $\%$ & & \\
\hline \multicolumn{9}{|c|}{ Contraceptive methods } \\
\hline No & 46 & 44.2 & 58 & 55.8 & 104 & 100 & \multirow{7}{*}{29.2} & \multirow{7}{*}{0.001} \\
\hline $\mathrm{COCP}$ & 4 & 10.5 & 34 & 89.5 & 38 & 100 & & \\
\hline IUCD & 2 & 25.0 & 6 & 75.0 & 8 & 100 & & \\
\hline Progesterone & 10 & 76.9 & 3 & 23.1 & 13 & 100 & & \\
\hline Barrier & 8 & 47.1 & 9 & 52.9 & 17 & 100 & & \\
\hline Coitus interrupts & 3 & 23.1 & 10 & 76.9 & 13 & 100 & & \\
\hline Tubal ligation & 0 & 0 & 7 & 100 & 7 & 100 & & \\
\hline \multicolumn{9}{|c|}{ Sexual history } \\
\hline Active & 48 & 35.0 & 89 & 65.0 & 137 & 100 & 0.4 & 0.5 \\
\hline Inactive & 25 & 39.7 & 38 & 60.3 & 63 & 100 & & \\
\hline \multicolumn{9}{|c|}{ Medical history } \\
\hline Normal & 69 & 41.8 & 96 & 58.2 & 165 & 100 & 11.5 & 0.001 \\
\hline Abnormal & 4 & 11.4 & 31 & 88.6 & 35 & 100 & & \\
\hline \multicolumn{9}{|c|}{ Gynecological operations } \\
\hline No & 61 & 38.4 & 98 & 61.6 & 159 & 100 & 1.1 & 0.2 \\
\hline Yes & 12 & 29.3 & 29 & 70.7 & 41 & 100 & & \\
\hline \multicolumn{9}{|c|}{ Surgical operations } \\
\hline No & 33 & 24.8 & 100 & 75.2 & 133 & 100 & 23.4 & 0.001 \\
\hline Yes & 40 & 59.7 & 27 & 40.3 & 67 & 100 & & \\
\hline
\end{tabular}


Table 8. Distribution of women characteristics according to Pap results.

\begin{tabular}{ccccc}
\hline Variable & Normal Pap & Abnormal Pap & $F$ & $P$ \\
\hline Age at marriage (years) & $23.1 \pm 4.3$ & $16.9 \pm 4.6$ & 9.1 & 0.001 \\
Gravidity & $5.8 \pm 2.2$ & $5.5 \pm 2.4$ & 0.9 & 0.3 \\
Parity & $4.5 \pm 1.8$ & $4.7 \pm 2.3$ & 0.6 & 0.5 \\
Abortion & $1.9 \pm 0.8$ & $1.2 \pm 0.7$ & 4.1 & 0.001 \\
Age at first delivery (years) & $24.3 \pm 4.4$ & $18.5 \pm 5.2$ & 7.7 & 0.001 \\
Menarche (years) & $13.3 \pm 0.8$ & $12.5 \pm 1.6$ & 3.5 & 0.001 \\
Frequency of coitus/week & $3.2 \pm 1.6$ & $2.8 \pm 1.4$ & 1.4 & 0.1 \\
Interval between marriage and Pap test (years) & $17.3 \pm 9.6$ & $17.5 \pm 10.7$ & 0.1 & 0.8 \\
\hline
\end{tabular}

Values are presented as mean $\pm \mathrm{SD} ; \mathrm{n}=200$ women.

the risk of Cervical Cancer in those girls [18]. The present study indicates that $63.5 \%$ of Pap results were abnormal, which is higher than that reported in Iraq by Barzanji, et al. (2013) that recorded only $12.2 \%$ of abnormal Pap results [19]. In the present study, abnormal Pap test results were significantly associated with age group 41 - 50 years, which was consistent with that reported by Kritpetcharat, et al. in Thailand (2012) and approximately similar to the UK records, where $60 \%$ of women with abnormal Pap results occurred in women with age less than 50 years [20]. Utilization of Pap test with associated diagnostic measures and treatment decreases the incidence of all histologic types and stages of invasive cervical cancer, and the benefit increases with age [21]. The present study revealed that abnormal Pap test results were significantly associated with women married with age $\leq 18$ years. This finding is consistent with that reported by Uribe-Perez et al. study in Colombia (2006) [22], which indicates that women with pre-malignant or malignant cervical lesions were younger, and start their sexual intercourse earlier with more sexual partners than healthy women. Moreover, Baram et al. (2007) reported increased abnormal Pap test results with early sexual activities in USA [23], and the association between cervical cancer and early marriage was clearly defined in many developing countries [24]. In 2013, Barazanji et al. reported significant association between duration of marriage and the incidence of cervical cancer in Iraqi women [19], and the similar was reported in the present study. Additionally, the current study revealed no significant association between Pap test results with residence, occupation and socioeconomic history, which was inconsistent with that reported in India [25]; this inconsistency might be attributed to difference of in sample size and the difference in socioeconomic status between countries. In this study smoking was not associated significantly with abnormal Pap results because of low prevalence of smoking habit among Iraqi women, while this factor seems highly correlated with abnormal Pap results in other communities where women smock heavily [26]. In addition to the importance of many other factors that determine the Pap results, including menstrual cycle irregularity, method of contraception and the surgical history [25] [27] [28], early marriage represents the most powerful variable that determine the incidence of abnormal Pap results according to the outcome of the present study. This finding was consistent with the reports of UNICEF on the effect of early marriage, as it may be translated into repeated pregnancies at a tender age when the body is not fully prepared for child bearing [29]. The lack of enforcement renders legislations against child marriage ineffective, and many efforts are highly recommended through media campaigns and educational outreach programs to achieve the target. Meanwhile the governments need to take responsibility for stopping this practice. Local, regional and national governments can also implement health outreach programs, preventive and treatment services for girls and boys regarding all issues of reproductive and sexual health [30]. Similar to other cross sectional studies, difficult assessment temporal relationship, inappropriate laboratory techniques, and non-homogenous sampling are the major limitations of the present study.

\section{Conclusion}

Among many associated variables, binary logistic regression analyses revealed that early marriage was the mostly effective determinant of abnormal Pap results in Iraqi women. 


\section{Acknowledgements}

The authors thank the Arab Board of Gynecology and Obstetrics for supporting the project and the medical staff of Elweyia Maternity Teaching Hospital for technical assistance.

\section{Competing Interests}

The authors declared that they have no competing interests.

\section{References}

[1] Ferlay, J., Soerjomataram, I., Dikshit, R., Eser, S., Mathers, C., Rebelom, M., et al. (2015) Cancer Incidence and Mortality Worldwide: Sources, Methods and Major Patterns in GLOBOCAN 2012. International Journal of Cancer, 136, E359-E386. http://dx.doi.org/10.1002/ijc.29210

[2] Nawal, M.N. (2009) Child Marriage: A Silent Health and Human Rights Issue. Reviews in Obstetrics and Gynecology, 2, 51-56.

[3] ICO Information Centre on HPV and Cancer (2014) Iraq Human Papilloma Virus and Related Cancers, Fact Sheet 2013. www.hpvcentre.net

[4] Al-Alwan, N.A. (2001) Colposcopy, Cervical Cytology and Human Papilloma Virus Detection as Screening Tools for Cervical Cancer. East Mediterranean Health, 7, 100-105.

[5] Sreedevi, A., Javed, R. and Dinesh, A. (2015) Epidemiology of Cervical Cancer with Special Focus on India. International Journal of Women's Health, 7, 405-414.

[6] Thakur, A., Gupta, B., Gupta, A. and Chauhan, R. (2015) Risk Factors for Cancer Cervix among Rural Women of a Hilly State: A Case-Control Study. Indian Journal of Public Health, 59, 45-48. http://dx.doi.org/10.4103/0019-557X.152862

[7] UNICEF Innocenti Research Centre. Early Marriage: Child Spouses, 2001. www.Unicef-icdc.org

[8] Goodman, A. (2015) HPV Testing as a Screen for Cervical Cancer. British Medical Journal, 350, h2372. http://dx.doi.org/10.1136/bmj.h2372

[9] Rodriguez, A.C., Schiffman, M., Herrero, R., Hildesheim, A., Bratti, C., Sherman, M.E., et al. (2010) Longitudinal Study of Human Papilloma Virus Persistence and Cervical Intraepithelial Neoplasia Grade 2/3: Critical Role of Duration of Infection. Journal of National Cancer Institute, 102, 315-324. http://dx.doi.org/10.1093/jnci/djq001

[10] Edelstein, Z.R., Madeleine, M.M., Hughes, J.P., Johnson, L.G., Schwartz, S.M., Galloway, D.A., et al. (2009) Age of Diagnosis of Squamous Cell Cervical Carcinoma and Early Sexual Experience. Cancer Epidemiology Biomarkers and Prevention, 18, 1070-1076. http://dx.doi.org/10.1158/1055-9965.EPI-08-0707

[11] Getahun, F., Mazengia, F., Abuhay, M. and Birhanu, Z. (2013) Comprehensive Knowledge about Cervical Cancer Is Low among Women in Northwest Ethiopia. BMC Cancer, 13, 2. http://dx.doi.org/10.1186/1471-2407-13-2

[12] Chumnan-Kietpeerakool, Y.P., Kriangsak, J., Usanee, S. and Jatupol, S. (2009) Knowledge, Awareness, and Attitudes of Female Sex Workers toward HPV Infection, Cervical Cancer, and Cervical Smears in Thailand. International Journal of Gynecology and Obstetrics, 107, 216-219. http://dx.doi.org/10.1016/j.ijgo.2009.07.023

[13] Sriplung, H., Singkham, P., Iamsirithaworn, S., Jiraphongsa, C. and Bilheem, S. (2014) Success of a Cervical Cancer Screening Program: Trends in Incidence in Songkhla, Southern Thailand, 1989-2010, and Prediction of Future Incidences to 2030. Asian Pacific Journal of Cancer Prevention, 15, 10003-10008. http://dx.doi.org/10.7314/APJCP.2014.15.22.10003

[14] Kjaer, S.K., van den Brule, A.J.C., Svare, E.I., Engholm, G., Sherman, M.E., Poll, P.A., et al. (1998) Different Risk Factor Patterns for High-Grade and Low-Grade Intraepithelial Lesions on the Cervix among HPV-Positive and HPVNegative Young Women. International Journal of Cancer, 76, 613-619. http://dx.doi.org/10.1002/(SICI)1097-0215(19980529)76:5<613::AID-IJC1>3.0.CO;2-T

[15] IARC (2007) IARC Monograph for Evaluation of Carcinogen Risks in Human. International Agency for Research on Cancer, Lyon.

[16] Solomon, D., Davey, D., Kurman, R., Moriarty, A., O’Connor, D., Prey, M., et al. (2002) The 2001 Bethesda System: Terminology for Reporting Results of Cervical Cytology. Journal of American Medical Association, 287, 2114-2119. http://dx.doi.org/10.1001/jama.287.16.2114

[17] Nour, N.M. (2006) Health Consequences of Child Marriage in Africa. Emergency Infectious Diseases, 12, $1644-1649$. http://dx.doi.org/10.3201/eid1211.060510

[18] Kuhn, L., Denny, L., Pollack, A., Lorincz, A., Richart, R. and Wright, T. (2000) Human Papillomavirus DNA Testing 
for Cervical Cancer Screening in Low Resource Settings. Journal of National Cancer Institute, 92, 818-825. http://dx.doi.org/10.1093/jnci/92.10.818

[19] Barzanjy, B.K., Talat, L.M. and Ismail, S.A. (2013) Cervical Dysplasia: Assessment and Risk Factors among Women Attending the Maternity Teaching Hospital in Erbil, Kurdistan-Iraq. Zanco Journal of Medical Sciences, 17, $286-293$. http://dx.doi.org/10.15218/zjms.2013.0004

[20] Kritpetcharat, O., Wutichouy, W., Sirijaichingkul, S. and Kritpetcharat, P. (2012) Comparison of Pap Smear Screening Results between Akha Hill Tribe and Urban Women in Chiang Rai Province, Thailand. Asian Pacific Journal of Cancer Prevention, 13, 5501-5504. http://dx.doi.org/10.7314/APJCP.2012.13.11.5501

[21] Sasieni, P., Castanon, A. and Cuzick, J. (2009) Effectiveness of Cervical Screening with Age: Population Based CaseControl Study of Prospectively Recorded Data. British Medical Journal, 339, b2968. http://dx.doi.org/10.1136/bmj.b2968

[22] Uribe-Perez, C.J., Diaz-Martinez, L.A., Ortiz-Serrano, R. and Meza-Duran, E.E. (2006) Pap Smear Prevalence and That of Pre-Malignant and Malignant Cervical Lesions amongst Women Living in the Carmen Initiative Demonstration Area, Bucarmanga, Colombia. Revista Colombiana de Obstetricia y Ginecologia, 57, 10-18.

[23] Baram, D.A. and Basson, R. (2007) Sexuality, Sexual Dysfunction, and Sexual Assault. In: Berek, J.S., Ed., Berek \& Novak's Gynecology, 14th Edition, Lippincott Williams \& Wilkins, Philadelphia, 313-349.

[24] Sultana, R. and Sultana, N. (2012) Clinical Profile and Treatment Protocol of Invasive Carcinoma of Cervix. Bangladesh Medical Journal (Khulna), 45, 11-14.

[25] Singh, S. and Badaya, S. (2012) Factors Influencing Uptake of Cervical Cancer Screening among Women in India: A Hospital Based Pilot Study. Journal of Community Medicine and Health Education, 2, 1-6. http://dx.doi.org/10.4172/2161-0711.1000157

[26] Tay, S.K. and Tay, K.J. (2004) Passive Cigarette Smoking Is a Risk Factor in Cervical Neoplasia. Gynecology Oncology, 93, 116-120. http://dx.doi.org/10.1016/j.ygyno.2003.12.032

[27] Cleland, J., Conde-Agudelo, A., Peterson, H., Ross, J. and Tsui, A. (2012) Contraception and Health. The Lancet, 380, 149-156. http://dx.doi.org/10.1016/S0140-6736(12)60609-6

[28] Fouda, L.M. and Elkazeh, E.A. (2014) The Impact of an Educational Intervention on Women's Knowledge and Perception Regarding Cervical Cancer and Human Papilloma Virus Vaccines in Tanta City: Applying Health Belief Model. Life Science Journal, 11, 289-297.

[29] Raj, A., Saggurti, N., Winter, M., Labonte, A., Decker, M.R., Balaiah, D. and Silverman, J.G. (2010) The Effect of Maternal Child Marriage on Morbidity and Mortality of Children under 5 in India: Cross Sectional Study of a National Representative Sample. British Medical Journal, 340, b4258. http://dx.doi.org/10.1136/bmj.b4258

[30] Osakinle, E.O., Babatunde, J.O. and Alade, F.A. (2013) Youths and Their Choice of Contraceptives towards an Effective Reproductive Health: The Case of Ekiti State, Nigeria. European Scientific Journal, 9, 193-202. 